\title{
DAMAGES FOR MENTAL SUFFERING RESULTING FROM MISTREATMENT OF A CADAVER
}

$T_{\text {he Recovery of damages for mental disturbance is usually limited }}$ to those instances in which the suffering is a reasonable and natural consequence of a physical or pecuniary injury to the plaintiff. ${ }^{1}$ However, damages are recoverable for mental suffering resulting from the mistreatment of dead bodies notwithstanding the absence of physical or pecuniary injury to the plaintiff. ${ }^{2}$ Abuse of a cadaver invades the socalled quasi-property right ${ }^{3}$ which exists in the surviving spouse or next of kin for the purpose of burial. ${ }^{4}$ The infringement of this right is a breach of duty or contract. ${ }^{5}$ Recovery of damages is usually denied, however, when the injury is caused merely by negligence, unaccompanied by wilful or wanton conduct. ${ }^{6}$

A recent California case, Carey v. Lima, Salmon \& Tully Mortuary, ${ }^{7}$ is one of a small minority of cases which does not require proof of wilful or wanton conduct to recover damages for mental suffering resulting from the mistreatment of dead bodies. ${ }^{8}$ In that case the

${ }^{2}$ I 5 AM. Jur. Dead Bodies $\$ 35$ (1938).

${ }^{2}$ Larson v. Chase, 47 Minn. 307 , 50 N.W. 238 (I89x).

${ }_{25}$ C.J.S. Dead Bodies $\$ 2$ (1941). The authorities are almost uniform in holding that there is no property right in a strict sense, or in the ordinary use of the term, in the dead body of a human being. After burial the body becomes a part of the ground to which it is committed. JaCKson, LaW of Cadavers I33 (2d ed. 1950). See Prosser, TORTS \& I I (2d ed. 1955); Note, 2 Ark. L. Rev. I24 (I948).

'Larson v. Chase, 47 Minn. 307,50 N.W. 238 (I891) (where the court talked in terms of a "sacred trust").

"The general rule that there can be no recovery for mental disturbance for the breach of a contract, was discarded by the court in the case of a mortician where the parties contracted with the reference to feelings and sentiments and knew that peculiar mental disturbance would result from a breach. Taylor v. Bearden, 6 Tenn. Civ. App. 33 (1915). Contra, Archer v. Continental Assur. Co., ro7 F. Supp. I45 (W.D. Ky. I952); Koerber v. Patek, I23 Wis. 453, 102 N.W. 40 (rg05).

'Dunahoo v. Bess, I46 Fla. 182, 200 So. 54I (194I); Plummer v. Hollis, 213 Ind. 43, II N.E.2d 140 (1937); Beaulieu v. Great No. Ry., 103 Minn. 47, x 14 N.W. 353 (1907); Nail v. McCullough, 88 Okla. 243, 212 Pac. 981 (I923); Grill v. Abele Funeral Home, Inc., 69 Ohio App. 5I, 42 N.E.2d 788 (1940); Nichols v. Central Vt. Ry., 94 Vt. 14, I09 Atl. 905 (I9I9). Restatement, TORTs \$868 (1939).

335 P.2d I8 I (Cal. 1959).

${ }^{8}$ Louisville \& N.R.R. v. Hull, $x_{3}$ Ky. 56I, 68 S.W. 433 (Ig02); Wells, Fargo. \& Co. Express v. Fuller, $1_{3}$ Tex. Civ. App. 610, 35 S.W. 824 (1896). A widow recovered from the railroad for the negligent misdelivery of the body of her husband in Hale v. Bonner, 82 Tex. 33, 77 S.W. 605 ( 1891 ). In Brown Funeral 
plaintiffs recovered damages for the mental disturbance they experienced when the defendant-morticians negligently failed properly to embalm their father's body for burial in a distant city.

Generally, recovery for the mental suffering caused by injuries to personal and domestic security, such as breach of promise to marry, false imprisonment, or libel, is facilitated because the requisite element of malice or wantonness is presumed. ${ }^{9}$ In contrast, most courts continue to require definite allegations and proof of malice for recovery for wrongful acts committed against a dead body. ${ }^{10}$ The usual rationale is that in mere negligence there is intent neither to offer indignity to the corpse nor to wound the feelings of the plaintiff. ${ }^{11}$ Furthermore, mental disturbance is deemed so remote and beyond ordinary probabilities that no proximate, causal relationship exists between the defendant's negligence and the alleged injury. ${ }^{12}$

If actions sounding in contract are brought, the majority of cases hold that there can be no recovery ${ }^{13}$ because the mental disturbance is deemed to be neither foreseeable nor in the minds of the parties when the contract was made. ${ }^{14}$ Some jurisdictions, however, reason that those who derive profit from preparing the dead for burial should be

Home \& Ins. Co. v. Baughn, 226 Ala. 66r, 148 So. 154 (1933), and Taylor v. Bearden, 6 Tenn. Civ. App. 33 (1915), an embalmer owing only ordinary skill was held liable for negligent and unskillful embalming. Contra, Dunahoo v. Bess, 146 Fla. 182, 200 So. 54I (194x); Beaulieu v. Great No. Ry., 103 Minn. 47, 114 N.W. 353 (1907). However, note the dissenting opinion in Beaulient v. Great No. Ry., supra, where it was felt that mere negligence was sufficient grounds to recover "sentimental" damages.

${ }^{\circ}$ Hall v. Jackson, 24 Colo. App. 225, I34 Pac. I5I (1913). In Larson v. Chase, 47 Minn. $307,310,50$ N.W. 238,240 (1891), the court pointed out that substantial damages could be recovered in a class of torts where the only injury suffered was mental: "That mental suffering and injury to the feelings would be ordinarily the natural and proximate result of knowledge that the remains of a deceased husband had been mutilated is too plain to admit of argument."

${ }^{10}$ Hall v. Jackson, supra note 9; Dunahoo v. Bess, 146 Fla. 182, 200 So. 541 (1941); Gadbury v. Bleitz, I33 Wash. 134, 233 Pac. 299 (1925).

${ }_{11}$ Boyle v. Chandler, 33 Del. 323, 138 Atl. 273 (1927).

${ }_{13}$ Hall v. Jackson, 24 Colo. App. 225, 132 Pac. 151 (1913); Dunahoo v. Bess, 146 Fla. 182, 200 So. 541 (1941). Recovery was denied for a mortician's breach of contract in failing to take a photograph of the plaintiff's deceased infant child for the purpose of preserving the memory of the child in Plummer v. Hollis, 213 Ind. 43, II N.E.2d 140 (1937).

${ }^{13}$ Dunahoo v. Bess, supra note 12.

14 Ibid. Accord, Grill v. Abele Funeral Home, Inc., 69 Ohio App. 51,42 N.E.2d 788 (1940), in which the plaintiff was denied recovery for negligent breach of contract when he failed to prove that the defendant-mortician's employees "maliciously" snatched jewelry from the body of his dead wife prior to burial. The defendant was guilty only of a violation of instructions or a mere breach of contract for which the plaintiff suffered only mental disturbance which was insufficient for recovery. 
especially aware of the deep emotional ramifications of their conduct. ${ }^{15}$ Thus, mental suffering is considered foreseeable $\mathrm{e}^{\mathbf{1 6}}$ and the proximate result of any breach of duty or contract. ${ }^{17}$ These courts view any indignity to a dead body, intentional or negligent, as, by its very nature, sufficient ground of recovery in contract for resulting mental anguish. ${ }^{18}$

There are exceptional areas in the law of cadavers where courts, which normally require a showing of wilfulness, allow recovery for mere negligent infliction of mental disturbance. The so-called "Texas rule," for example, permits recovery for mental anguish resulting from the negligent mishandling of telegraphic death messages. ${ }^{20}$ An extension of the "Texas rule" has also found some acceptance in cases of negligent misdelivery or mistreatment of a dead body by common carriers. ${ }^{21}$

The basic rationale of the telegraph and common-carrier decisions is that, since the parties contract with full awareness of the peculiar emotional and sentimental elements associated with transactions concerning dead bodies, no showing of conduct exceeding mere negligence is necessary. Such considerations seem no less compelling in the case of a contract with a mortician for the preparation of a body for burial. ${ }^{22}$

\footnotetext{
${ }^{18}$ Louisville \& N.R.R. v. Hull, 113 Ky. 561, 570, 68 S.W. 433, 435 (1902). The law awards damages for mental disturbance caused by a breach of contract, since in the case of a dead body the parties contracted with respect to sentiments and feelings, "or at least have contracted with respect to those things which naturally affect the feelings and emotions." In Taylor v. Bearden, 6 Tenn. Civ. App. 33 (1915), the court found that the parties contracted with reference to feelings and sentiments, and knew that severe mental disturbance would result from a breach. See also, Chelini v. Nieri, $32 \mathrm{Cal}$. 2d 480, 196 P.2d 915 (1948).

${ }^{10}$ Spiegel v. Evergreen Cemetery Co., II7 N.J.L. 90, 186 Atl. 585 (1936). Here the court found that a negligent act in burying the deceased, when the family was over one-half hour late, was in effect utter disregard for the feelings of others amounting to recklessness.

${ }^{17}$ Sanford v. Ware, I9I Va. 43, 60 S.E.2d 10 (1950).

${ }^{18}$ Brown Funeral Home \& Ins. Co. v. Baughn, 226 Ala. 661, 148 So. 154 (1933); Chelini v. Nieri, 32 Cal. 2d 480, 196 P.2d 915 (1948); Louisville \& N.R.R. v. Hull, 113 Ky. 561,68 S.W. 433 (1902).

${ }^{10}$ Renihan v. Wright, 125 Ind. 536,25 N.E. 822 (189o). But of., Dunahoo v. Bess, 146 Fla. I82, 200 So. 54I (1941), where the court rejected the theory after reviewing its historical development.

${ }^{20}$ Jackson, op. cit. supra note 3 , at 150 . These cases also represent a strong exception to the rule which denies recovery for mental disturbance caused by a breach of contract. See note I4 supra.

${ }^{21}$ Louisville \& N.R.R. v. Hull, 113 Ky. 561, 68 S.W. 433 (1902); Wells, Fargo \& Co. Express v. Fuller, ${ }_{13}$ Tex. Civ. App. 610, 35 S.W. 824 (1896).

"Brown Funeral Home \& Ins. Co. v. Baughn, 226 Ala. 66r, 148 So. 154 (1933); Taylor v. Bearden, 6 Tenn. Civ. App. 33 (1915). Justice Pound said in his concurring opinion: "An indignity to the dead is an offense to the living." Finley v. Atlantic Transp. Co., 220 N.Y. 249, 259, 115 N.E. 715, 718 (1917).
} 
The traditional approach requiring a positive showing of wilfulness or wantonness ${ }^{23}$ in this class of cases is unrealistic. ${ }^{24}$ The majority view is often justified by raising the spectre of fraudulent claims. ${ }^{25}$ It seems obvious, however, that the usual close kinship and sentimental attachment of the plaintiff to the loved-one whose remains are violated insure the existence of genuine mental disturbance and greatly obviate the danger of feigned claims. ${ }^{26}$ Accordingly, many courts, when faced with mere negligent conduct and with precedents embodying the traditional approach, nonetheless allow recovery by resorting to legal fictions ${ }^{27}$ and judicial niceties. ${ }^{28}$

The traditional approach concerning dead bodies represents a definite inadequacy in the law for the recovery of damages for mental dis-

${ }^{23}$ See note 6 supra.

"Hall v. Jackson, 24 Colo. App. 225, 134 Pac. 151 (1913). All that the court would do was suggest a legislative enactment to allow a recovery for mere negligence. "And we think it may be safely laid down as a general rule that an injury to any right recognized and protected by the common law [referring to the quasi-property right in the next of kin for purposes of burial] will, if the direct and proximate consequence of an actionable wrong, be a subject for compensation." Larson v. Chase, 47 Minn. $307,310,50$ N.W. 238,239 (189I).

${ }_{20}$ Cf., Comstock v. Wilson, 257 N.Y. 23 I, 177 N.E. 43 I (193I); Mitchell v. Rochester Ry., 151 N.Y. 107, 45 N.E. 354 (1896) (at common law, claims based on mental disturbance wore the badge of fraud).

${ }^{20}$ See note 9 supra.

${ }^{27}$ Renihan v. Wright, 125 Ind. 536,25 N.E. 822 (1890). Here the defendantmortician negligently allowed the body of an infant child to be buried in a spot unknown to himself. When the parties asked where their child was, he answered, "Your child is im Ohio." The court allowed recovery for mental disturbance for breach of a contract of bailment. Obviously this is a judicial fiction since only property can be bailed. Other courts go no further than recognizing a quasi-property right in the corpse which is in itself a fiction, as the property right did not exist while the decedent is living, cannot be conveyed, has no pecuniary value, and has only one purposeburial, which actually is a source of liability to the next of kin.

${ }^{28}$ In Boyle v. Chandler, 33 Del. 323, $3^{8}$ Atl. 273 (r927), the defendant's act amounted to transferring a corpse from one coffin to a smaller, but more expensive, unselected coffin in order to insure prompt delivery for burial. The railroad could not accept the selected larger coffin in the absence of a shipping box which at that time was unavailable and thus the reason for the exchange. The plaintiff was charged no increase in price, but still recovered for mental anguish, since the jury found a gross indignity was heaped upon the deceased. In Mensinger v. O'Hara, I89 Ill. App. $4^{8}$ (1914), the plaintiff was allowed to recover for wilfulness because fortunately he did not allege mere negligence in the declaration. The court inferred wilfulness from the complaint. See Sworski v. Simons, 208 Minn. 201,293 N.W. 309 (1940), where compensation was awarded to decedent's parents when a coroner acting under the alleged anthority of a statute had the deceased embalmed. It was held that the statute was not a defense, for it required that the deceased be an unknown person, and the evidence tended to show that there was sufficient identification upon the body for the coroner to have discovered its identity. 
turbance. This inadequacy would best be remedied by a frank admission that negligent mutilation or indignity to human remains is sui generis, ${ }^{29}$ and damages for mental disturbance should be awarded without proof of aggravated misconduct. ${ }^{30}$ Total abandonment of the anachronistic traditional approach would be a realistic and salutary innovation. ${ }^{81}$

\footnotetext{
${ }^{20}$ Taylor v. Bearden, 6 Tenn. Civ. App. 33 (1915).

${ }^{30}$ Lamm v. Shingleton, 231 N.C. 10, 55 S.E.2d 810 (1949) (the contract being so personal in nature, the contractual duty or obligation is so coupled with inatters of mental concern or solicitude, that a breach of that duty will necessarily or reasonably result in mental suffering). See Owens v. Liverpool Corp., [1939] I K.B. 394 (C.A. 1938) (where defendant's servants negligently overturned a hearse and the relatives of the deceased recovered for mental distrubance even though they did not see the accident).

"II "Bnt I am ready to concede that the rule of adherence to precedent, though it ought not to be abandoned, ought to be in some degree relaxed. I think that when a rule, after it has been duly tested by experience, has been found to be inconsistent with the sense of justice or with the social welfare, there should be less hesitation in frank avowal and full abandonment." Cardozo, The Nature of the Judicial Process I 50 (1921).
} 